\begin{tabular}{|c|c|c|}
\hline $2002,42-46$ & $\begin{array}{c}\text { ETHICS IN SCIENCE AND ENVIRONMENTAL POLITICS } \\
\text { ESEP }\end{array}$ & Published September 26 \\
\hline
\end{tabular}

\title{
The challenges of energy
}

\author{
Mark Moody-Stuart* \\ 9, Gun House, 122, Wapping High Street, London E1W 2NL, United Kingdom
}

\begin{abstract}
People all over the world want energy, personal transportation and economic development, but at the same time many of them are concerned about the environmental consequences. Accepting the work of the Inter-Governmental Panel on Climate Change (IPCC) as a sound starting point, it is suggested that it will be technologically possible to arrive at a climate change scenario at the lower end of the IPCC forecast range of outcomes. While the climatic effects of such an outcome would have significant impact, it should be possible to take mitigating steps. But to ensure that technologies and consumption patterns do in fact evolve along the lines suggested a combination of regulatory frameworks will be needed within which the market can operate to deliver significant improvements in the impact of transportation and power generation.
\end{abstract}

Resale or republication not permitted without written consent of the publisher

Energy is an essential ingredient of modern life. There is little doubt that a world where we were dependent on the strength of our own limbs or those of domestic animals could not support the present global population. And the way of life of those who could be supported in such a world would be radically different, with choices significantly constrained.

There is no doubt that energy in the developed world can be used very much more efficiently so that the demand for energy can be reduced. But energy demand overall will continue to grow. Energy demand has grown by $80 \%$ since 1970, with developing countries taking an increasing share. With the bulk of the world's people still in the full flight of development, energy consumption could grow even faster. By 2030 the world could be consuming twice as much as now $-60 \%$ of it in today's developing countries. Furthermore we have an urgent need to address the needs of the almost 2 billion people, one third of the world's population, who have no access at present to modern sources of energy. What does this mean for the world in which we live and for the choices which we will have to make? Analyses of the

*E-mail: markmoodystuart@aol.com energy issue need to focus on 2 aspects: power and transportation.

Talking to energy company customers all over the world we find that people have very much the same wants and worries. Whether in Africa, China, Europe, India or the United States, people want to have access to reliable and economic energy at the flick of a switch or the turn of a key. Reliability, availability and economy are all very important to them. But at the same time people worry about the consequences of this availability. They worry about the local environmental impact and they worry increasingly about the global impact on our climate.

People also want access to personal transportation. Sometimes we in the developed world forget the liberation and independence that personal transportation brought to us half a century ago. The ability to reach other parts of our country, the ability to bring our produce to market. This is what many people in developing countries aspire to also. First to own a motor scooter or motor cycle and then a car. But at the same time they worry about the consequences of this. The traffic jams and the local pollution. In 5 years time will it take 3 hours to drive across Mumbai or Beijing, and will we choke to death in the process? 
People want personal and national economic development. Those who have very little at present aspire to some security of livelihood. Some who are better off also worry about inequality. They feel uncomfortable with the inequality which they see in their own countries and perhaps even more by the inequality that they see in other countries on their television screens. But will it be possible to bring others up to an acceptable standard of living, let alone one equal to theirs, without blowing the global environment apart? Does this really mean that some will have to accept a reduction in their present standards in order to achieve sustainable equity.

An energy company has to address the wants and needs of its customers. It has to meet their immediate needs, but at the same time address their concerns. This is not to solve their concerns, or to tell them not to worry, but to say that energy companies share their concerns and are prepared to work with society, using their expertise to find solutions. This is not a matter of morality. It is a matter of good business to meet the needs of your customers and to address their concerns.

These issues strike at the heart of sustainable development, both in the definition of the Brundtland report 'Our Common Future' - meeting the needs of the present generation without prejudicing the ability of future generations to meet theirs - as well the concept that sustainability means addressing not just economic issues but environmental and societal ones also. A corporation has to meet the needs of its customers - serving customers is what business is all about. But it also has to make sure that it performs to acceptable environmental standards and that it looks at the societal impact of its activities. Most people would accept that a business that performs well economically but is not responsible environmentally will be punished by its customers. Equally, a business that has an environmentally impeccable performance but which fails to make a profit will cease to be a business and shortly after that will cease to exist at all. But the future of a business which is seen to operate in way that is contrary to the interests of society will also be under threat.

This is true not just of businesses, but of all organisations. An NGO or government which fails to secure its economic leg will also have problems. And equally, an NGO which pursues a purely environmental agenda without regard for the needs of society will be marginalised.

Clearly, we have to meet the energy needs of society. For an energy corporation to fail to do so is to court extinction. But it is no less dangerous for a government. For in a democracy, energy companies' customers are also a governments voters. But equally, it is important for both governments and companies to work together to ensure that the concerns are being addressed.

\section{HOW DO WE RECONCILE ECOLOGICAL AND ECONOMIC NEEDS?}

We could rely on technology. And technology is delivering results while we meet the needs of the market. For instance, there is a popular perception that vehicle emissions are growing. In reality, vehicle emissions of major pollutants in Britain fell by a third to a half during the 1990s, despite a $12 \%$ increase in mileage - and are forecast to do so again by 2010 .

The climate threat represents a more fundamental challenge for a world which clearly depends on fossil energy to support rising living standards. Anyone who has read the scientific section of the Third Assessment Report of the Inter-Governmental Panel on Climate Change (IPCC 2001) cannot fail to be impressed by a solid and unemotional piece of work. I commend it to you. This is the quality of work on which we in business base our investment decisions. The range of uncertainty is clearly identified, as are the assumptions.

I think the upper end of the range of the estimates is as unlikely as it is undesirable - a simple extrapolation from the present. The lower end results from a doubling of atmospheric carbon dioxide concentrations from pre-industrial levels. It assumes significant - but entirely achievable-changes in energy patterns. They show carbon dioxide climbing to about $550 \mathrm{ppm}$ — raising temperatures by $2^{\circ} \mathrm{C}$ (range 1.4 to $3.2^{\circ} \mathrm{C}$ ), and sea levels by $30 \mathrm{~cm}$ (range 10 to $55 \mathrm{~cm}$ ), by the end of the century. I believe the emission patterns which would stabilise atmospheric carbon dioxide at this level are achievable, and the resulting changes are probably tolerable-although we would need to adapt. Long-term energy scenarios projected by Shell — estimating energy demand to 2050 - show 2 routes assuming normal technological rates of change by which carbon dioxide could be stabilised at around 550 ppm. One assumes a world in which renewable energy is developed rapidly, the other one in which the emphasis is on an economy turning to hydrogen as an energy carrier. There is little doubt that technological solutions can be developed, with changes of magnitudes and rates similar to the changes that we have seen over the last few decades.

The industry has a long record of successful technological change. Perhaps the most important extension of energy choice during my career has been the expansion of gas consumption - previously largely confined to North America. Gas was in direct competition with fuel oil, which then accounted for nearly $40 \%$ of European oil sales. Fortunately, we were able to crack surplus heavy oil and add hydrogen to it to satisfy the growing demand for transport fuels. Gas has great competitive advantages for heating and power genera- 
tion, as a source of ultra-clean liquids to help meet rising fuel standards, and - potentially — as a source of hydrogen for fuel cells. Emitting much less carbon than coal and negligible sulphur, gas is a vital fuel for reducing greenhouse emissions, as well as improving air quality in developing cities. Gas consumption could double - perhaps grow threefold - by 2030.

Extending gas use and developing new forms of energy such as gas-to-liquids, hydrogen fuel-cells and renewables-overcoming technological challenges and fierce competition - requires long-term commitment. The pioneering Shell Middle Distillate Synthesis plant at Bintulu was built in the late 1980s, when I was in Malaysia. With this experience, and many difficult lessons, we can now build second generation plants, competitive with liquid natural gas for commercialising remote gas.

People have been pursuing the potential of fuel cells for over a century. At Shell we worked on them 30 years ago before concluding they could not then compete and donating our experimental car to the Science Museum in London. They are now very definitely back on the agenda: for distributed power generation and transportation.

Many companies are investing heavily to develop renewable energy businesses: solar, wind, biomass, geothermal. Much progress is being made. For example, in wind energy, the latest turbines generate 10 times the power at a third of the cost of their 1990 predecessors. The relentless, competitive drive to innovate, experiment, improve productivity, offer new choices and discard the unsuccessful - in response to market signals - is a powerful spur to technological progress.

But how do we ensure that energy patterns evolve in a way that delivers these desirable results while meeting the needs of society?

\section{WHAT CAN RESPONSIBLE BUSINESS DO TO ABATE CLIMATE CHANGE?}

The recognition of the need for precautionary action is not new. I have already referred to the efforts made over the years with motor manufacturers on emissions from automotive fuels. In the case of climate, both Shell and BP acknowledged the challenge in 1997, in the case of Shell in our 1996 annual report (Shell 1997). The progress made on the Kyoto Protocol (however limited and imperfect that agreement may be) is extremely important. Time and again in business we see that an enormous amount of effort is expended to debate whether some new step is really necessary, what should be the parameters and how devastating to our business the costs are going to be. Time and again in business we see that once agreement is reached and targets are set, the situation changes. All the creativity goes into achievements, not arguing over what we should be doing. This mindset change delivers remarkable results. We have seen this in relation to lead in petrol, and time and again we see it when we set cost targets in companies.

But I must warn you that it takes time. In 1997 Shell set out a structured response to climate changereducing own emissions over 5 years to $10 \%$ below 1990 levels, offering customers a choice of fuels, including renewable energy and hydrogen, experimenting on internal 'cap and trade systems', putting the cost of carbon into investment calculations, and working on pilot projects for Clean Development Mechanisms. This is a complex issue, and even in an energy company it took about 2 years to really get understanding of the issues into people around the business. You have to get decision-makers to think about carbon in their day to day commercial decisions - that is why putting carbon costs into investment proposals is so vital. It makes it an integral part of normal business. It will take even longer for business in general to get used to thinking in terms of the environmental costs of carbon, and perhaps only now are many businesses starting. But there are limits to what business can do on its own.

\section{WHAT CAN BUSINESS AND GOVERNMENT DO TOGETHER WITH CONSUMERS TO ABATE CLIMATE CHANGE?}

Can we rely on consumers making the right choices and guiding the path of development? I believe only partly. Experience shows that for the common good to be achieved or protected, we will need collective action or rules governing acceptable behaviour agreed upon by society. What do we need from governments and what from business?

Governments provide a regulatory framework, business works in commercial markets within that framework. Both have to bear in mind that this has to be in line with the wishes of the consumer. If not, we are out of business or/and they out of government.

\section{Power generation}

I believe 3 levels of framework are required to manage power generation:

(1) Green House Gas reducing 'cap and trade system'. The first step, to begin at all, is most important. The UK government has taken that step. We need to start really measuring the emissions linked to power 
generation. Exxon has called for mandatory measurement and reporting of actual current emissions by large energy users all around the world. The tentative step taken recently by the Bush administration works in the direction of encouraging business to record and reduce its emissions. This would help set a reliable baseline. But even if we start now it will take time-it takes years for even an energy company to fully understand the ramifications of its own emissions. Then there is the essential emissions trading system. Experimental systems show that the cost of carbon emissions avoided varies greatly in different parts of the energy business. The clearing cost is a few dollars only. Some responses, e.g. solar photovoltaics, are currently at about 2000 dollars/ton. That is why it is so good that the Kyoto Protocol has been agreed upon. We must learn to think about emissions in the day to day workings of business. This can lead to many savings. We should not start with a general emissions tax; taxation should come in form of a penalty if you do not meet your reduction target (by self or trade). And the penalty should be related to the clearing cost of the traded market-say double, with a high cap. This expands the market.

(2) Portfolio standards for energy production. These are necessary to encourage the new technologies which need to be developed. Under this system a government sets a framework (e.g. $10 \%$ ) for the amount of electrical energy to be produced from renewable sources (in a wide sense), without specifying any particular technology, and the market operates within that framework. There should be no attempt to pick or mandate technologies. Let the market and the trading system find the cheapest and easiest way of meeting the portfolio standards. Consider an example from Texas, USA. Prudently, the State of Texas wants a small percentage of renewable energy in its electricity supply. Suppliers can either generate the energy themselves or trade it in - or be fined more than the market clearing price. Because of the low percentage of the fine and the existence of some federal tax breaks, this has a negligible impact on costs. So consumers, who are also of course voters, support it. As a result of this regulation-driven but market-based approach, targets for renewable energy have been exceeded - mostly through wind energy, as ranchers are happy to lease land to wind developers. Renewable sources have an important role in providing clean and efficient energy to the more than 1 billion people who must rely on firewood or animal waste-and suffer badly from the physical burden, damage to health, and exclusion from amenities. In rich countries, we tend to take energy for granted. Those who lack it are more appreciative.

(3) Building and lighting efficiency standards. These are required to ensure that best practice is followed in new installations and buildings. Again there should be a specification of performance standards, but no detailed regulation of how to achieve them. Let the market find the cheapest and easiest method. And again, if we can get everyone involved to think about the effects of carbon emissions all the time, we can make great progress.

Consumers (and voters) will generally accept the sound sense of 'cap and trade systems', but they do not influence such systems directly. Consumers will also accept the wisdom of portfolio standards as a sensible approach to the diversification of energy sources, as long as they work and do not result in markedly increased costs.

\section{Transportation}

There are 2 levels of framework required.

(1) Efficiency standards for vehicles. We should not mandate the type of motor to propel a vehicle, just the level of efficiency and very simple emission controls. Let the market operate and the consumer choose within those standards. I believe the consumer will accept this, just as we have accepted seat belts.

(2) Taxation of vehicles. This should be based on the vehicle's fuel consumption. If you want a really inefficient beast, you should just pay the tax for it up frontnot in the form of fuel taxes. British Chancellor of the Exchequer Gordon Brown has tested the limits of what his customers are prepared to pay in fuel tax. And no politician in the US will even think of it!

But a third effort needs to be made - to engage the consumer. In my opinion it is no good trying to force people into public transport. We will use it where it offers a convenient alternative (millions use it in London for the convenience of its current infrastructure, in spite of its operation failures). A European environmental minister once asked me how to get people off their love affair with the motor car. I believe we should not even try and interfere with that love. It is deeply imbedded. But the love is with personal movement and space and the freedom that it brings, not with the internal combustion engine per se.

We have to make eco-efficiency as fashionable as 4wheel drive vehicles. We need to use the powers of social pressure and the attraction of beautiful engineering. This is not hair shirt stuff - it should be ecohedonism - taking pleasure from both comfort, operating performance as well as eco-efficiency. The efficient alternative has to deliver the performance. My wife and I drive a Toyota Prius gasoline-electric hybrid. It is a beautiful piece of engineering - air conditioned, quiet, responsive when needed, with a top speed of $100 \mathrm{mph}$, but excellent consumption and 
emission characteristics. We derive great pleasure from it (including a rather wicked feeling of superiority as we travel silently and efficiently!) and it costs less than a BMW. There are some very exciting approaches also by Amory Lovins' Hypercar - aimed at delivering efficiency (100 mpg equiv) and performance (range and acceleration, as well as payloads like a US vehicle, with corresponding safety). We must not expect the customer en masse to suddenly want to drive milk floats or ride bikes - and that applies as much in the developing world where the real growth will come. What we can ensure is that their fleets and their electrical generators are much more efficient and modern than ours have been - but it has to start in the developed world.

Is there a moral issue in all of this? If you believe that society agreeing on ways of meeting its needs while framing regulation to ensure that behaviour which works against the common good is discouraged is a moral approach, then yes. But one could just as well characterise this as enlightened self interest on the part of society. Or on the part of business.

The key is to develop the right regulatory frameworks which mandate the end desired by society (but not the means) and which leave the market to find

Editorial responsibility: R.J.(Sam) Berry,

London, United Kingdom (through competition) the most economical and effective means - which will be the choice of individual customers within that framework.

There are 3 key desirables:

- A regulatory framework in which the market can work

- Getting 'carbon thinking' into the day to day economic decisions of business

- Meeting the needs of the customer in an eco efficient way

The 3 undesirables (or impossibilities!) are:

- Regulation which freezes and restricts creativity

- Expecting our customers (or voters) to give up something (through moral choice?)

- Expecting the developing world to do something we do not do.

\section{LITERATURE CITED}

IPCC (2001) Climate Change 2000. Third assessment report of the Intergovernmental Panel on Climate Change. Cambridge University Press, Cambridge

Shell (1997) Annual report for 1996

Submitted: September 4, 2002; Accepted: September 7, 2002 Proofs received from author(s): September 13, 2002 Published on the web: September 26, 2002 